\title{
$ノ-1$
}

\section{ダブルチャンバー方式電気加熱気化装置を用いる誘導結合プラズマ 発光分析法による米中カドミウムの迅速定量}

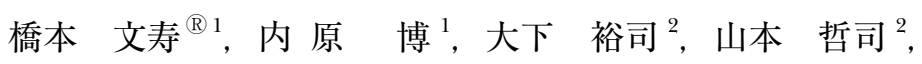

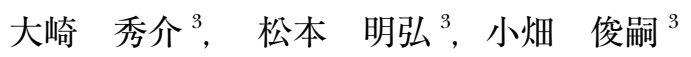

\section{1 緒言}

近年, 食の安全が重要視されている中, 迅速かつ高感度 な分析方法がスクリーニング分析法として採用されること への期待が高まっている. 厚生省告示第 370 号「食品, 添 加物等の規格基準」によって定められている無機元素の分 析方法は, 試料を化学的な前処理によって分解し, 原子吸 光光度計などを用いて分析する ${ }^{1)}$.この方法は, 非常に煩 雑で時間がかかる. そこで, 微量元素の迅速及び高感度分 析を実現するために電気加熱気化（ETV）装置と誘導結合 プラズマ発光分析装置（ICP-AES）を接続 ${ }^{2)}$ 14) して測定す る方法を検討した．この方法を用いて固体試料を直接測定 することで試料を化学的な前処理なしに目的元素を迅速か つ高感度に測定することが可能であった。

本研究では, 粉末にした米をタングステンキュベットに 科量し，それをダブルチャンバー方式の $\mathrm{ETV}^{14)}$ に載せ，乾 燥及び灰化の段階を経て, 蒸発の段階で測定対象元素であ るカドミウムを直接プラズマへ気化導入することによりカ ドミウムの定量を行った.

\section{2 実験及び結果}

\section{$2 \cdot 1$ 装置と試薬}

本研究には, HORIBA JOBIN YVON 製の誘導結合プラ ズマ発光分析装置 ULTIMA2 に洛陽技研製 RH-21 原子スペ クトル用加熱気化器（ETV）を接続して用いた．装置全体 の概略図を Fig. 1 に示す. ダブルチャンバー方式の ETVの 特徵は既に報告した ${ }^{14)}$.

検量線作成用の標準試料には, 国立環境研究所より頒布 されているカドミウムの濃度が異なる 3 種類の玄米粉末標 準試料 NIES CRM No. 10-a $\left(\mathrm{Cd} 0.023 \pm 0.003 \mu \mathrm{g} \mathrm{g}^{-1}\right)$, No. 10-b $\left(\mathrm{Cd} 0.32 \pm 0.02 \mu \mathrm{g} \mathrm{g}^{-1}\right)$ 及び No. 10-c $(\mathrm{Cd} 1.82 \pm 0.06$

\footnotetext{
${ }^{1}$ 株式会社堀場製作所 : 601-8510 京都府京都市南区吉祥院宮の 東町 2

${ }^{2}$ 洛陽技研株式会社 : 613-0023 京都府久世郡久御山町野村村東 118

3 和歌山県工業技術センター：649-6261 和歌山県和歌山市小倉 60
}

$\left.\mu \mathrm{g} \mathrm{g}^{-1}\right)$ を用いた。 カドミウムの標準溶液は，和光純薬工 業製の JCSS 認証標準液 $\left(1000 \mathrm{mg} \mathrm{L}^{-1}\right)$ を使用し, 適宜, 純水で所定の濃度に希釈した。 その他の試薬については, 和光純薬工業製の有害金属測定用を用いた.

\section{$2 \cdot 2$ 試料調製}

カドミウムを意図的に含浸させた米粉末（以下，カドミ ウム含浸米と記す）を作製するため，市販の白米をめのう 乳鉢ですり潰し， 3 個のビーカーに各々 $2 \mathrm{~g}$ を精秤して取 り，ビーカー内の米粉が完全に浸るように水を加えてから カドミウム標準溶液 $0.1 \mathrm{mg} \mathrm{L}^{-1}, 1 \mathrm{mg} \mathrm{L}{ }^{-1}$ 及び $10 \mathrm{mg} \mathrm{L}^{-1}$ をそれぞれのビーカーに $2 \mathrm{~mL}$ ずつ加えた．これをビーカ ーごと乾燥機に入れ, $70^{\circ} \mathrm{C}$ で一昼夜放置して乾燥させた. 乾燥した米粉は, 再度, めのう乳鉢ですり潰し $1 \mathrm{~mm}$ 以下 に粒径を揃えた。試料調製時のカドミウム含有濃度の目標 值は, $0.1 \mu \mathrm{g} \mathrm{g}^{-1}$ (低濃度品), $1 \mu \mathrm{g} \mathrm{g}^{-1}$ (中濃度品) 及び $10 \mu \mathrm{g} \mathrm{g}^{-1}$ (高濃度品) の 3 水準とし, これを実験用の試料 とした.

3 種類のカドミウム含浸米の正確な濃度を求めるため に, 試料を湿式酸分解してICP-AESにより定量した. 試料 $0.2 \mathrm{~g}$ を $50 \mathrm{~mL}$ のビーカーに精秤して硫酸 $2 \mathrm{~mL}$ 加えホッ トプレート上にて試料を炭化し, 硫酸白煙が生じるまで穏 やかに加熱した．試料が完全に炭化したのを確認し室温ま で泠却した後に硝酸 $1 \mathrm{~mL}$ を加え, 再びコニカルビーカー をホットプレート上で加熱した．この操作では完全に炭化 物が分解し, 内容液の色が微黄色になるまで硝酸添加の操 作を繰り返した。これを室温まで放冷し， $20 \mathrm{~mL}$ メスフラ スコに移し純水で定容し ICP 発光分光分析装置でカドミウ ムの定量分析を行った。

\section{$2 \cdot 3$ 標準操作}

玄米粉末標準試料 NIES CRM No. 10 及びカドミウム含 浸米は, 試料 $10 \mathrm{mg}$ をタングステンキュベットに $10 \mu \mathrm{g}$ の 桁まで正確に量り取り，ピンセットを用いてチャンバー内 の電極に固定されたタングステンボート上に載せ ${ }^{1213)}$, 可 動式の石英製インナーチャンバーを下ろし，アウターチャ 


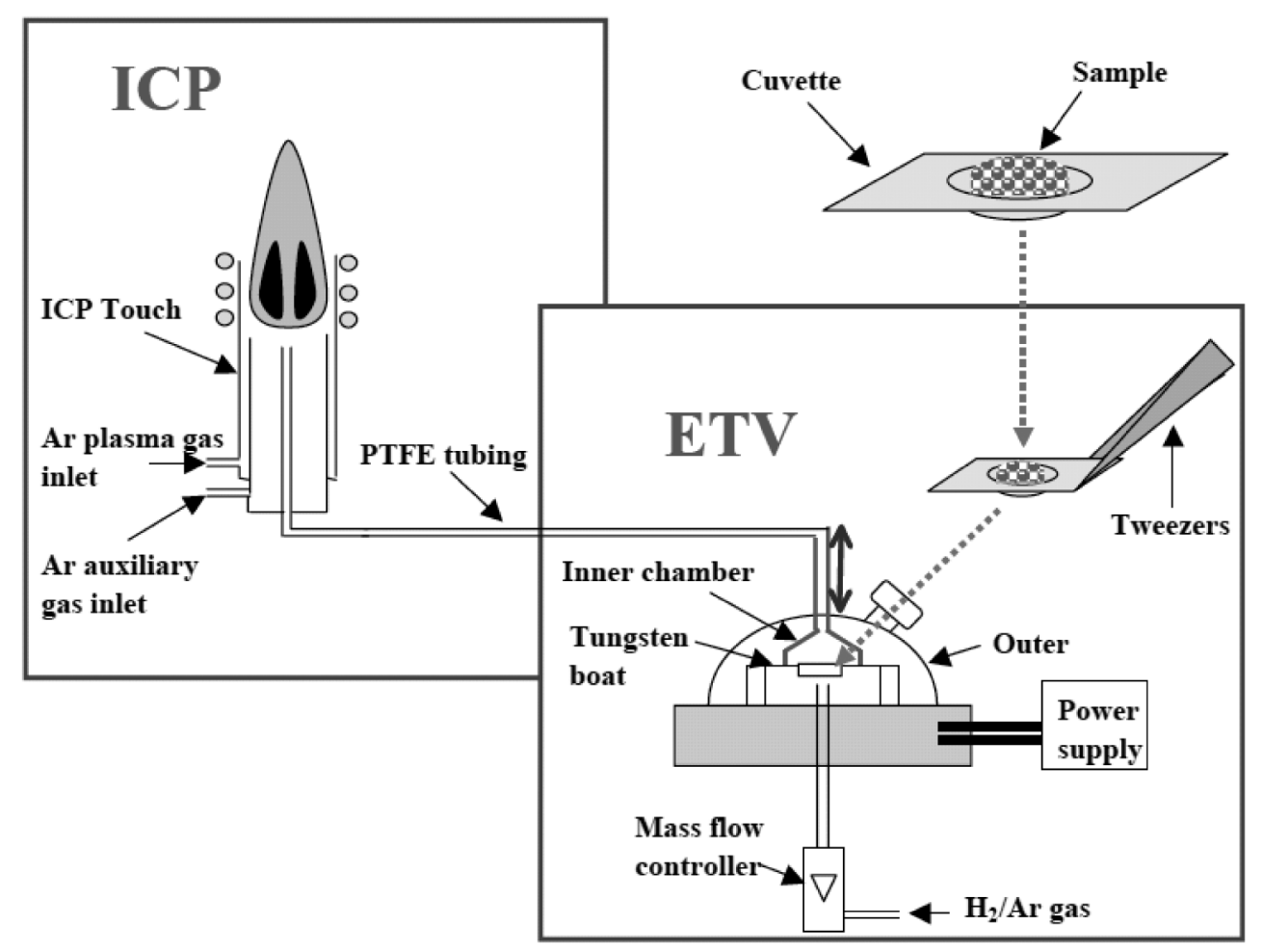

Fig. 1 Schematic diagram of the ETV-ICP-AES

Table 1 Instrument operating conditions

\begin{tabular}{lc}
\hline \multicolumn{2}{l}{ ICP-AES (HORIBA JOBIN YVON ULTIMA2) } \\
Frequency power & $1.2 \mathrm{~kW}$ \\
Plasma gas flow rate & $12 \mathrm{~L} \mathrm{~min}^{-1}$ \\
Analytical line & $\mathrm{Cd}(\mathrm{II}) 214.438 \mathrm{~nm}$ \\
Electric thermal vaporizer (Rakuyo Giken $\mathrm{Rh}-21)$ \\
Drying & $160^{\circ} \mathrm{C}$ for $20 \mathrm{~s}(\mathrm{ramp} 5 \mathrm{~s})$ \\
Ashing & $190^{\circ} \mathrm{C}$ for $40 \mathrm{~s}(\mathrm{ramp} 90 \mathrm{~s})$ \\
Vaporizing & $1900^{\circ} \mathrm{C}$ for $2 \mathrm{~s}$ \\
Carrier gas & $\mathrm{H}_{2}(7 \%)-\mathrm{Ar}$ \\
Carrier gas flow rate & $0.6 \mathrm{~L} \mathrm{~min}{ }^{-1}$ \\
\hline
\end{tabular}

ンバーを密栓して, Table 1 に示す加熱条件で乾燥及び灰 化し蒸発の段階でカドミウムを気化させた.この時, ICP から発光されるカドミウムの強度をピーク面積として測定 した. 玄米粉末標準試料 NIES CRM No. 10 の保証值は乾燥 重量あたりの值であるが, 本研究では迅速定量を目的とす るためすべての操作を新鮮重量べースに換算して行った. ちなみに玄米粉末標準試料 NIES CRM No. 10 の水分減量 は, 約 $5 \%$ である.

\section{$2 \cdot 4$ 測定条件の最適化}

$\mathbf{2 \cdot 4 \cdot 1}$ インナーチャンバーの位置＼cjkstart測定時のインナ ーチャンバーの高さは, その高さの違いによってチャンバ 一内の気流の方向性が異なり, それによってプラズマへの 試料導入効率が異なると考え, タングステンボートに近い

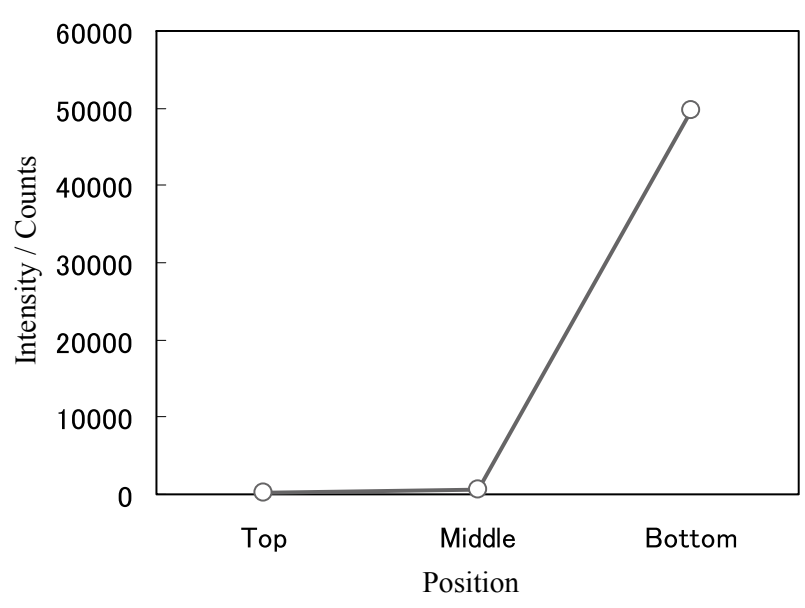

Fig. 2 Effect of the position of the inner chamber on the Cadmium emission intensity $(\bigcirc)$

位置から Bottom, Middle, Top として, それぞれの位置 におけるカドミウムの発光強度を確認した．強度の確認に は，玄米粉末標準試料 NIES CRM No. 10-C を使用した。そ の結果を Fig. 2 に示す. この結果より, カドミウムの発光 強度は Bottom の位置で最大となることが確認できた。こ れはインナーチャンバーの効果によって, 気化された試料 を効率良く試料密度が高い状態でプラズマ内に導入できた ことによるもので, Bottom の位置で最大となる点につい

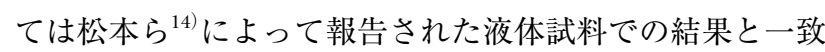


する．以上より，インナーチャンバーは Bottom の位置と した.

\section{$\mathbf{2 \cdot 4 \cdot 2}$ 温度変化によるガス膨張のためのガス流量の測}

定最適な気化温度を検討するために，気化温度を変化 させてプラズマを通過する時のキャリアーガスのガス流量 を調べた。この実験は, タングステンボート上には試料を 置かずにキャリアーガスのみを流し, 試料の気化段階で最 大となるガス膨張による流量を流量計により測定した. キ ヤリアーガス流量は, $0 \mathrm{~L} \mathrm{~min}^{-1}, 0.3 \mathrm{~L} \mathrm{~min}^{-1}$ 及び $0.6 \mathrm{~L} \mathrm{~min}^{-1}$ で比較した. その結果を Fig. 3 に示す. いずれの流量であ ってもガス膨張によるガス流量は, タングステンボートの 温度が上昇するに従い大きくなり， $1800^{\circ} \mathrm{C}$ 付近の温度で 一定となった。再現性の良いデー夕を得るためには, チャ ンバー内の温度が多少変化してもガス膨張による流量が一 定に維持される条件が良いと考え, 気化温度を $1900^{\circ} \mathrm{C} に$ し、キャリアーガス流量を $0.6 \mathrm{~L} \mathrm{~min}^{-1}$ とした.

\section{$\mathbf{2 \cdot 5}$ カドミウム含浸米の簡易定量}

玄米粉末標準試料 NIES CRM No. 10-a， b， c で検量線を 作成し, 3 種類のカドミウム含浸米を定量した.この結果,

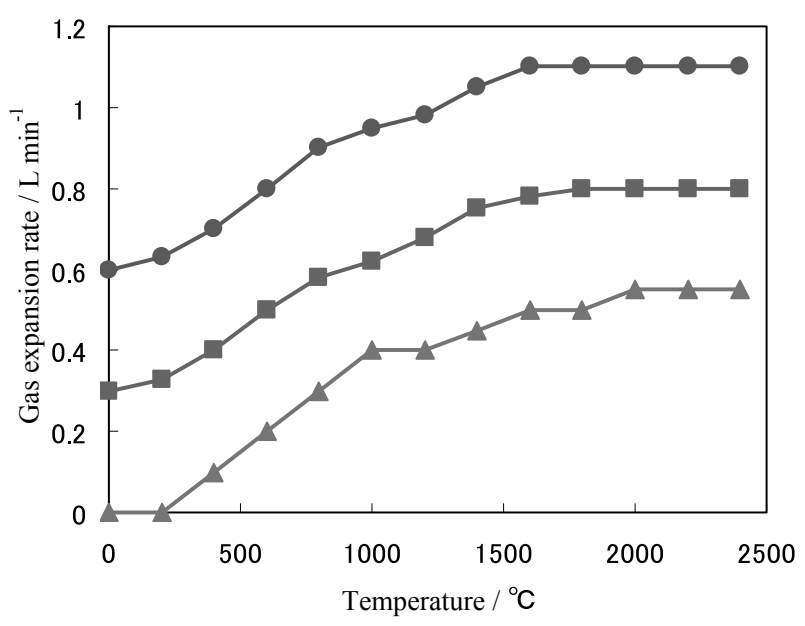

Fig. 3 Effect of temperature on expansion rate Carrier gas flow rate : $0.6 \mathrm{~L} \mathrm{~min}^{-1}, 0.3 \mathrm{~L} \mathrm{~min}^{-1}$, $\Delta 0 \mathrm{~L} \mathrm{~min}^{-1}$
本法による分析值は湿式酸分解法に比較して，およそ $40 \%$ 高い值で得られたが, 相関係数は $R=0.999$ と非常に良好 な結果であった．分析值に対する再現性は，カドミウム含 浸米の中濃度品で相対標準偏差が $8.1 \%$ と高めの值であっ たが, 低濃度品, 高濃度品では, 相対標準偏差が $5 \%$ 以下 と良好な結果を得た。低濃度品 $0.1 \mathrm{ppm}$ は, 食品衛生法に 基づく食品規格基準の $0.4 \mathrm{ppm}$ を十分に下回る感度を有し ており，スクリーニング法としては十分対応できる結果で あった。

著者らは，本法での分析值がおよそ $40 \%$ 高い值で得ら れた原因が，標準試料と含浸試料の試料間におけるマトリ ックス成分の違いによる影響と考えた。認証標準物質は玄 米粉末であり, カドミウム含浸米は白米粉末であるため, 厳密には含有される成分が異なる，そこで，マトリックス の影響を小さくするため ICP の高周波出力を $1.2 \mathrm{~kW}$ から $1.3 \mathrm{~kW}$ に上げ, キャリアーガス流量を $0.6 \mathrm{~L} \mathrm{~min}^{-1}$ から 0.3 $\mathrm{L} \min ^{-1}$ に下げることでプラズマ温度を上げ，有意差を検 証した，その結果を Table 2 に示したが, Operation condition2では, 湿式酸分解法での定量結果により近い值を得 た.これは, プラズマ温度の上昇によりロバストなプラズ マ状態が形成され，マトリックスの違いによる定量值への 影響を抑制できたためと考える. しかしながら一方で, 再 現性については相対標準偏差が, 低濃度品で $15 \%$, 中濃度 品及び高濃度品で $10 \%$ と悪化した。この悪化した原因は, ガス流量 $0.6 \mathrm{~L} \mathrm{~min}^{-1}$ では, 気化温度 $1900^{\circ} \mathrm{C}$ での流量が $1.09 \pm 0.02 \mathrm{~L} \mathrm{~min}^{-1}$ であったのに対して,ガス流量 0.3 $\mathrm{L} \mathrm{min}^{-1}$ では $0.79 \pm 0.02 \mathrm{~L} \mathrm{~min}^{-1}$ となり, 気化時のチャン バー内の温度変化による流量変動が大きくなったためと考 える.

以上の結果から，マトリックスモディファイヤーを使用 しなくとも, 測定条件を最適化することで, 米中のカドミ ウムを $10 \%$ 程度のバラッキで定量できた。 これらの結果 より，本法はスクリーニング法として十分に使用できると 考える.

\section{3 結 $\quad \overrightarrow{\bar{a}}$}

本研究では, ダブルチャンバー方式のETVを用いて米粉

Table 2 Determination of cadmium in the cadmium impregnated rice

\begin{tabular}{|c|c|c|c|}
\hline \multirow{2}{*}{ Sample } & \multirow{2}{*}{$\begin{array}{l}\text { Wet decomposition- } \\
\text { ICP-AES } / \mu \mathrm{g} \mathrm{g}^{-1}\end{array}$} & \multicolumn{2}{|c|}{ ETV-ICP-AES $/ \mu \mathrm{g} \mathrm{g}^{-1}$} \\
\hline & & Operating conditions $1^{\text {a) }}$ & Operating conditions $2^{\mathrm{b})}$ \\
\hline Low level & $0.100 \pm 0.002^{c)}$ & $0.137 \pm 0.006^{\mathrm{d})}$ & $0.124 \pm 0.018^{\mathrm{d})}$ \\
\hline Middle level & $0.97 \pm 0.02^{c)}$ & $1.12 \pm 0.09^{\mathrm{d})}$ & $1.06 \pm 0.11^{\mathrm{d})}$ \\
\hline High level & $9.9 \pm 0.2^{c)}$ & $14.1 \pm 0.5^{c)}$ & $10.5 \pm 1.1^{\mathrm{d})}$ \\
\hline
\end{tabular}

a) Power : $1200 \mathrm{~W}$, Carrier gas flow rate : $0.6 \mathrm{~L} \mathrm{~min}^{-1}$. b) Power : $1300 \mathrm{~W}$, Carrier gas flow rate : $0.3 \mathrm{~L} \mathrm{~min}^{-1}$. c) The mean value \pm standard deviation for 3 replicate determinations. d) The mean value \pm standard deviation for 5 replicate determinations. 
を直接，ICP に気化導入したことで，煩雑な前処理を省略 することができ, 1 検体を約 3 分で測定できる迅速な方法 となった．また，ETV 法によるカドミウム含浸米の定量結 果は, 湿式酸分解法による結果と近似であり, 食品規格基 準であるカドミウム濃度を十分に定量できる高感度分析法 であることから, 本法がスクリーニング法の一つとして有 用な手段であることを実証することができた。 また本法 は, 固体粉末試料に対して有効な手段であるため, 製粉, 製薬，化粧品などの分野への応用が期待できる.

$$
\left(\begin{array}{l}
2009 \text { 年 } 5 \text { 月, 第 } 70 \text { 回分析化 } \\
\text { 学討論会において一部発表 }
\end{array}\right)
$$

\section{文献}

1) 食品, 添加物等の規格基準, “第 1 食品 $\mathrm{D}$ 各条 ○穀類, 豆類及び野菜 2 穀類及び豆類の成分規格 の試験法 (2) カドミウム試験法”, 厚生省告示第 370 号 (昭和 34 年 12 月 28 日).

2) M. Resona, F. Vanhaecke, M. T. C. de LoosVollebregt: J. Anal. At. Spectrom., 23, 1450 (2008).

3) X. Hou, B. T. Joues : Spectrum., 23, 1450 (2008).
4) 久保田正明監訳: “誘導結合プラズマ質量分析法”, p. 152 (2000), (化学工業日報社) ; A. Monster (Ed.)： “inductively coupled Plasma Mass Spectrometry”, (1998), (Wiley-VCH, Inc., New York).

5) R. E. Sturgeon, J. W. Lam : J. Anal. At. Spectrom., 14, 785 (1999).

6) H. Isoyama, S. Okuyama, T. Uchida, M. Takeuchi, C. Iida, G. Nakagawa: Anal. Sci., 6, 555 (1990).

7) D. W. Boomer, M. Powell, R. L. A. Sing, E. D. Salin : Anal. Chem., 58, 975 (1986).

8) 金子 聡, 勝又英之, 鈴木 透, 太田清久: 分析化 学 (Bunseki Kagaku), 56, 535 (2007).

9) K. Chiba, M. Kurosawa, K. Tanabe, H. Haraguchi : Chem., Lett., 1984, 75 .

10) M. Suzuki, K. Ohta, T. Yamakita : Anal. Chem., 53, 9 (1981).

11) N. Shibata, N. Fudagawa, M. Kubota: Anal. Chem., 63, 636 (1991).

12) Y. Okamoto, R. Kikkawa, Y. Kobayashi, T. Fujiwara : J. Anal. At. Spectrom., 16, 96 (2001).

13) Y. Okamoto : J. Anal. At. Spectrom., 14, 1767 (1999).

14) 松本明弘, 大崎秀介, 小畑俊嗣, 大下裕司, 山本哲 司, 橋本文寿, 内原 博: 分析化学 (Bunseki Kagaku), 58, 393 (2009).

\title{
Rapid Determination of Cadmium in Rice by Inductively Coupled Plasma Atomic Emission Spectrometry with a Double Chamber Electrothermal Vaporization System
}

\author{
Bunji Hashimoto ${ }^{1}$, Hiroshi Uchinara ${ }^{1}$, Yuji Ohshita ${ }^{2}$, Tetsuji Yamamoto ${ }^{2}$, \\ Shusuke OsAKI $^{3}$, Akihiro MATsumoto ${ }^{3}$ and Toshitsugu KoBAta ${ }^{3}$
}

\footnotetext{
${ }^{1}$ HORIBA, Ltd., Analytical Application Center, 2, Miyanohigashi, Kisshoin, Minami-ku, Kyoto-shi, Kyoto 601-8510

${ }^{2}$ RAKUYO GIKEN Co, Ltd., 118, Murahigashi, Nomura, Kumiyama-cho, Kuse-gun, Kyoto 613-0023

${ }^{3}$ Industrial Technology Center of Wakayama Prefecture, 60, Ogura, Wakayama-shi, Wakayama 649-6261
}

(Received 15 December 2009, Accepted 22 February 2010)

In Japan the permitted maximum concentration of cadmium in whole-rice is regulated by the standard of the Food Sanitation Act. A typical method for the quantitative analysis of cadmium in whole-rice includes complicated and troublesome sample-preparation procedure. We propose to use an inductively coupled plasma atomic emission spectrometer connected to a doublechamber electro thermal vaporization (ETV) system to measure cadmium. This technique does not require any chemical preparation. A calibration curve to determine the cadmium concentration obtained by the ETV method has been made using the certification standard of Rice Flour (NIES No. 10). The obtained results of the cadmium concentration were compared with the value obtained by the wet decomposition method. A good correlation between the results has been shown. The ETV method could be used as a quick analytical way to measure the cadmium concentration in whole-rice within 3 minutes without any chemical sample preparation.

Keywords : ETV-ICP-AES ; cadmium ; rice ; double chamber ; without pretreatment. 